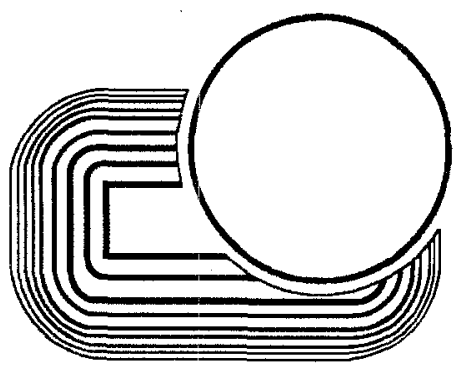

\title{
TIME-AVERAGING IN THE MARINE FOSSIL RECORD: OVERVIEW OF STRATEGIES AND UNCERTAINTIES
}

\section{SUSAN M. KIDWELL}

KIDWELL S.M. 1998. Time-averaging in the marine fossil record: overview of strategies and uncertainties. [Détermination de la durée d'accumulation dans le registre fossile marin: revue des stratégies et des incertitudes]. GEOBIOS, 30, 7: 977-995. Villeurbanne, le 31.03.1998.

Manuscrit déposé le 25.08.1997.

ABSTRACT - The paleontologic reasoning that led to the recognition of time-averaged assemblages in the early $1970 \mathrm{~s}$, and to elaborations of the concept in the 1980s and 1990s, has now undergone considerable actualistic testing, primarily using marine mollusks. These studies have confirmed the fundamental elements of the concept, including paleontologic estimates of the absolute durations and short-term dynamics of time-averaging: despite the rapid rates of shell destruction that can be documented in modern environments, death assemblages in nearshore and shelf settings are age-mixtures that have commonly formed over thousands to tens of thousands of years. Although many more actualistic studies are needed to document environmental and taxonomic variation, the results so far greatly increase our confidence in the indirect sedimentologic, stratigraphic, and paleontologic evidence used to evaluate assemblages in the older fossil record. The strategy outlined for evaluating fossil assemblages stresses breadth of evidence, most particularly geological context and origins of the host interval. Numerous questions remain. One is whether a "taphonomic clock" operates: does damage, either on an individual shell or for an assemblage overall, accrue at a sufficiently steady rate that it can be used to estimate the relative age of a shell (i.e., if it is from one of the earlier or from one of the later generations to be incorporated in the time-averaged assemblage), or used to estimate the duration of time-averaging in the overall assemblage (maximum range of shell ages)? Unfortunately, damage accrues very quickly apparently within molluscan assemblages (e.g. within the first few hundred years), so that assemblages that accumulate over much longer time scales (hundreds of thousands of years) do not differ significantly in taphonomic grade than those formed over a few thousand years. Comparative analysis of fossil assemblages suggests that other features, such as diagenetic heterogeneity and microstratigraphic complexity within host intervals, may be more useful "clocks" for ranking the time-resolution of assemblages, but these ideas need wider testing. Other uncertainties and directions for investigation are probable differences in the relative degrees and absolute durations of time-averaging (a) among major taxonomic groups, (b) among environments within single embayments, (c) through depositional sequences, owing to shifting rates of sedimentation as well as migrating environments, and (d) over the course of Phanerozoic time, owing to changes in the nature of skeletons produced as well as in the organisms that influence post-mortem preservation. We have testable hypotheses and even preliminary evidence for these larger scale patterns, and they are exciting avenues for future research.

KEYWORDS: TAPHONOMY, PALEOECOLOGY, BENTHIC, MARINE, TIME-AVERAGING.

RÉSUMÉ - Le raisonnement paléontologique qui a conduit à la reconnaissance de la durée d'accumulation des assemblages au début des années 1970 puis aux élaborations du concept dans les années 1980 et 1990, a désormais subi un test actualiste important en utilisant principalement les mollusques marins. Ces études ont confirmé les éléments fondamentaux du concept y compris les estimations paléontologiques des durées absolues et la dynamique à court terme de l'évaluation de la durée d'accumulation malgré les taux rapides de destruction des coquilles qui peuvent être observés dans les environnements actuels, les assemblages des sites littoraux et de plate-forme sont, quant à leur âge, des mélanges qui se sont communément constitués sur des milliers ou des dizaines de milliers d'années. Bien que des analyses actualistes plus nombreuses soient nécessaires pour documenter la variation environnementale et taxinomique, les résultats acquis accroissent fortement notre confiance dans les éléments indirects, sédimentologiques, stratigraphiques et paléontologiques utilisés pour apprécier les assemblages dans le registre fossile plus ancien.Les stratégies esquissées pour l'interprétation des assemblages fossiles font ressortir l'ampleur des preuves plus particulièrement pour le contexte géologique et les origines de l'intervalle concerné. De nombreuses questions demeurent. L'une est de savoir si une "horloge taphonomique" intervient: les dommages, soit d'une coquille particulière, soit d'un assemblage tout entier, parviennent-ils avec des taux suffisamment réguliers à contribuer à estimer l'âge relatif d'une coquille (c'est-à-dire si elle est de l'une des premières ou de l'une des dernières générations qui ont été incor- 
porées dans l'assemblage dont la durée d'accumulation est estimée), ou peuvent-ils être utilisés pour évaluer la durée d'accumulation de l'assemblage tout entier (répartition maximale des âges des coquilles)? Malheureusement, les dommages se réalisent très rapidement dans les assemblages de mollusques (par exemple dans les tout premiers cent ans) et ainsi les assemblages qui s'accumulent sur des périodes beaucoup longues (centaines de milliers d'années) ne different pas significativement de grade taphonomique de ceux formés en quelques milliers d'années. Une analyse comparative des assemblages fossiles suggère que d'autres faits, comme l'hétérogénéité diagénétique et la complexité microstratigraphique dans les intervalles concernés, peuvent être des "horloges" plus utiles pour le classement de la résolution temporelle des assemblages, mais ces idées exigent d'être plus largement testées. D'autres incertitudes et voies d'investigations concernent les différences probables dans les degrés relatifs et les temps absolus de la durée d'accumulation (a) parmi les groupes taxinomiques majeurs, (b) parmi les environnements de lieux protégés, (c) à travers des séquences de dépôt en raison des taux variables de sédimentation et des environnements migrants et (d) au cours du Phanérozoïque à cause des changements intervenus dans la nature des squelettes élaborés et dans celle des organismes qui influent sur la préservation post-mortem. Nous avons des hypothèses testables et même une preuve préliminaire pour ces patrons à plus grande échelle et ce sont là des voies stimulantes pour des recherches futures.

MOTS-CLÉS: TAPHONOMIE, PALÉOÉCOLOGIE, BENTHIQUE, MARIN, DURÉE D’ACCUMULATION.

\section{INTRODUCTION}

How much time is represented by an assemblage of fossils from a single bed or other narrowly defined stratigraphic interval? Does the set of cooccurring fossils represent an instantaneous "snapshot" of formerly coexisting organisms, or the remains of multiple generations, community states, or evolutionarily distinct faunas? The ability to answer these questions for individual fossil assemblages, both in relative and absolute time, is important to virtually all paleobiologic and historical geologic studies, because collections of fossils from single beds or sets of associated beds are the fundamental sampling increment for paleoecologic, morphometric/taxonomic, and species-level biostratigraphic and evolutionary studies.

This paper briefly discusses how scales of timeaveraging are evaluated in shallow marine macrobenthic records, using the well-studied mollusks as a primary source. Actualistic studies of modern death assemblages are corroborating the basic paleontologic tenets of time-averaging - for example, that mixed-age assemblages exist, and that the oldest generations represented in an assemblage leave a weaker signal than the youngest - and are also corroborating paleontologic estimates of absolute duration of time-averaging within habitats, thus increasing our confidence in paleontologic and geologic reasoning. This latter point is especially important for our confidence in evaluating time resolution in the older fossil record, particularly for taxonomic groups and sedimentary environments without modern analogs.

Many uncertainties remain, however, even for relatively well-studied mollusks. For example, is there a taphonomic clock - that is, can the condition of surviving fossils be used to gauge the degree of time-averaging in an assemblage? Also, are there large-scale patterns in time-resolution do analytically important differences in resolution exist among taxa, among environments, through depositional sequences (transgressive-regressive cycles), across paleolatitudes, or over the evolutionary sweep of Phanerozoic time? These questions of possible taphonomic megabias are as important for classical paleontologic investigations of single beds and outcrops as they are for broad biogeographic and evolutionary studies, because all rely on the fundamental reliability and comparability of individual fossil assemblages.

\section{WHAT IS TIME-AVERAGING? PALEONTOLOGIC REASONING}

"Time-averaging" is the process by which organic remains from different time intervals come to be preserved together. More precisely, following Walker and Bambach's (1971) original definition, it refers to situations where remains "accumulate from the local living community during the [relatively long] time required to deposit the containing sediment", and is the result of biological generation times typically being short relative to net rates of sediment accumulation, or of mixing depths in the sedimentary column being large relative to sediment accumulation. During timeaveraging, biological remains may undergo repeated burial/exhumation cycles due to physical reworking of host sediment, and may be mixed over tens of centimeters to a meter or more within the sedimentary column by bioturbation. The input of new dead material may be continuous or discontinuous over this period, and each cohort of dead material is subject to taphonomic culling as a function of tissue type, time in the system, and post-mortem environmental conditions. Moreover, 
the composition of dead input may itself change, owing to small-scale fluctuations in state of the local source community or changes in the environment. The final biomass of a time-averaged assemblage is thus expected to be completely different from the instanteous pictures of community structure provided by biological grab samples or mass kills. Time-averaged assemblages will also be fundamentally different from assemblages composed entirely or partially of exotic (allochthonous) elements.

Based on the geological context of fossil assemblages, paleontologists have recognized that the general phenomenon of time-averaging can operate over a broad range of time-scales, such that organic remains from successive generations, successive communities, and even successive chronozones can become amalgamated within a single bed or narrow stratigraphic interval (Fürsich 1978). For the practical purpose of grouping assemblages with biologically and taphonomically comparable degrees of time-resolution, and of distinguishing non-comparable assemblages, the spectrum of time-averaging can be subdivided into four qualitatively distinct categories (Kidwell $\&$ Bosence 1991), as follows.

Census assemblages (original term of Hallam 1972). These reflect zero or minimal timeaveraging of individuals, such as when mass death of all or some part of a community is followed by permanent burial, sealing the assemblage from later additions or modification. These are the closest paleontologic analogs of ecological grab samples or censuses of living communities in modern environments, and presumably also record the shortest periods of time. "Snapshot" is an excellent alternative term.

Although these assemblages have the highest time resolution, they are not necessarily unbiased pictures of the source community. For example, escape traces and missing life styles in a fossil assemblage (e.g., absence of vagile benthos and nekton) would suggest that some members of the community are missing in the final record; if mineralized hardparts are not accompanied by soft-tissues, then organisms composed exclusively of soft tissues are also absent and taphonomic omission is suspected. However, groups may be missing because of the ecology of death itself. Recent "mass mortalities" are rarely fatal to all species and ageclasses, much less to every living individual. Moreover, the peculiar taxonomic compositions of some fossil censuses suggest that, as in modern habitats, many ancient mass mortalities occurred during unusual rather than "everyday" conditions in the life of a community, for example coinciding with spawning or culminating a long period of stress, just as seen in many modern examples (Brett \& Seilacher 1991). The resulting assemblage is a temporally high-resolution "snapshot" that may nonetheless be biologically or taphonomically skewed, rather than a complete or random subsample of the source community.

In absolute terms, the time represented by a census assemblage could be truly instantaneous (days, weeks, single season of year), but in some instances could range up to several years owing to the prolonged nature of some mass mortalities and the long windows for carcass preservation afforded by some low-temperature or low-oxygen seafloors.

Within-habitat time-averaged assemblages (strict sense of Walker \& Bambach 1971). These are time-averaged over a period of relative environmental stability, so that only individuals from a single temporally persistent community are mixed. Short-term processes that mix successive generations and community states include bioturbation (both diffusive and advective movement of remains within the sedimentary column; this is inferred for homogeneously amalgamated beds, usually with pervasive burrow-mottling) and reworking (exhumation and redeposition of remains, associated with a fluctuating seafloor position; inferred for lithologically heterogeneous intervals, commonly with traces of anastomosing discontinuity surfaces or remnant sedimentary structures). The lower the long-term (net or background) rate of sediment accumulation on which these processes are superimposed, and/or the deeper the mixing/reworking depth, then the larger the number of generations that have potential to be mixed in the final assemblage.

Hypothetically, we can visualize situations where remains are added to the assemblage continuously over the interval of time-averaging; such records are relatively complete with respect to elapsed time (that is, most sub-increments of elapsed time are represented by fossils in the final assemblage; = "continuous time-averaging" of Fürsich \& Aberhan 1990). Alternatively, remains may be added and/or preserved only sporadically, for example associated with episodic events of mass mortality or storm reworking, resulting in a temporally less complete assemblage ("discontinuous time-averaging" of Fürsich \& Aberhan 1990).

Several independent lines of evidence suggest within-habitat time-averaged assemblages form over a range of absolute time-scales. These scales vary among environments but are on the order of a minimum of years and decades to a maximum of thousands or perhaps ten thousand years depending on the environment (Fig. 1). Indirect evidence used to reach these estimates (Kidwell \& Bosence 1991) includes: 
Biostratigraphically Condensed

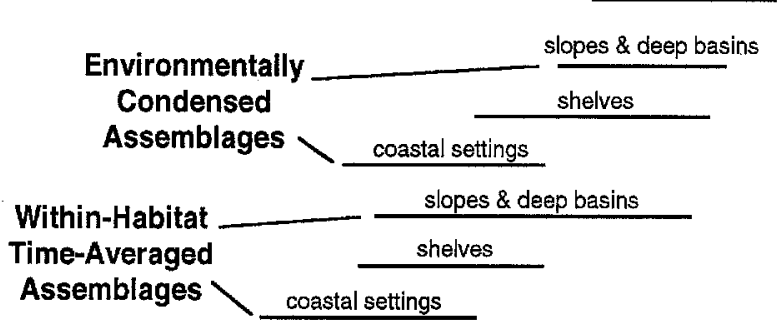

Census Assemblages

1 day 1 month 1 year $10 \mathrm{yr} 100 \mathrm{yr} 1 \mathrm{ky} 10 \mathrm{ky} 100 \mathrm{ky} 1 \mathrm{My} 10 \mathrm{My} 100 \mathrm{My}$ years of time-averaging per assemblage

FIGURE 1 - Estimated absolute durations for different relative scales of time-averaging in marine assemblages, inferred from dated biostratigraphic zones and estimates of average species durations, modern and ancient rates of facies migration, and data from biological and hydrographic studies in modern environments (from Kidwell \& Bosence 1991). The lines indicate the range of possible time-scales over which a particular degree of time-averaging might develop. Durées absolues estimées pour différentes échelles relatives de l'évaluation de la durée d'accumulation d'assemblages marins, inférées des zones stratigraphiques datées et des estimations de durée moyenne des espèces, des taux actuels et anciens de migration des faciès et des données fournies par les études biologiques et hydrographiques des environnements actuels (d'après Kidwell \& Bosence 1991). Les traits indiquent l'extension des échelles de temps possibles durant lesquelles pourrait se développer un degré particulier de la durée d'accumulation estimé.

a, hydrographic data on the minimum period over which storms and other physical perturbations become a steady-state process in Recent environments. This is the set of ordinary conditions preferred or survived by the resident benthic community, and thus indicates the minimum period of time-averaging for recurrent fossil assemblages; this is on the order of a few decades in coastal settings but on the order of a century for the open shelf; the lifespan of the longest-lived organisms in the target community provides another means of estimating these steady-state periods;

b, geological information on rates of habitat migration and facies change during Cenozoic transgressive-regressive cycles. This includes rates calibrated radiometrically and biostratigraphically; the longer the period that an environment remains stable in space, then the longer the maximum possible duration of within-habitat time-averaging (on the order of a few thousands of years maximum for shelf facies);

c, ecological information on the minimum number of years of replicate sampling of a living community that is required for the cumulative diversity curve to plateau. Several decades to a century are needed to sample molluscan communities adequately in temperate coastal and shelf settings; and, d, ecological information on the minimum number of years of replicate sampling necessary for cumulative live diversity to resemble the diversity of the local death assemblage. This is on the order of years for temperate coastal settings and many decades to a century for the open shelf.

Environmentally condensed assemblages (original term of Fürsich 1975). These are time-averaged over a period of environmental change, so that ecologically unrelated species become mixed. (The short-term processes and issues of temporal completeness that are of concern in within-habitat time-averaging also apply here.) Deciding how large an environmental change is necessary to categorize the assemblage as "environmentally condensed" depends on the scale of the paleobiologic question.

As an example of a very fine-scale definition, Fürsich \& Kauffman (1984) were able to distinguish seasonal salinity-controlled differences in faunal composition in some finely bedded Cretaceous lagoon deposits: beds that contained mixtures of both low-salinity and high-salinity faunas were categorized as environmentally condensed. In many lagoonal and other records, however, communities do not alternate so starkly on a seasonal basis: faunal variation may be a more complex and intergradational spatial and temporal mosaic, and thus the definition of a community or habitat is broader. In these circumstances, environmental condensation is recognizable only at a coarser, facies scale (e.g. subtidal lagoon versus lagoon margin, or lagoon versus open shelf, rather than season to season within the subtidal lagoon). Also, the question at hand might only require a coarser subdivision of environmental variability, for example if the aim were to compare the biodiversity of Cretaceous lagoons with those of the Paleogene, or of tropical lagoons and temperate lagoons. Kidwell \& Bosence (1991) suggested limiting the term environmental condensation to these coarser environmental changes that would normally yield distinct lithofacies (as opposed to distinct laminae within a facies). The question at hand, however, should determine the operational definition adopted in any given study.

In terms of absolute time, environmentally condensed assemblages by definition fall at the high end of within-habitat time-averaged assemblages, since environments must have time to change for different communities to be telescoped at a single site. For fine-scale condensation sensu Fürsich \& Kauffman (1984), two seasons could be sufficient to generate an environmentally condensed assemblage, whereas for facies-scale condensation sensu Kidwell \& Bosence (1991), individual assemblages probably signify at least multiple decades even in 
coastal settings where facies patches are small and can be quite mobile. Thousands of years are probably more typical minimum times on open shelves and deeper basin settings, where environmental bands are generally broader and driven by slower processes of climate change and transgression/ regression. Millenial-scale climatic "flickers" in the Pleistocene, for example, drove latitudinal shifts in species geographic ranges within a single sealevel highstand, so that species from two different biogeographic provinces can be time-averaged (environmentally condensed) within a single transgressive shellbed (Roy et al. 1996).

Biostratigraphically condensed assemblages (sensu Heim 1934). These are time-averaged over geologically long periods of time; species from successive chronozones are mixed within a single horizon or occur in very close stratigraphic succession. Such assemblages are commonly environmentally condensed as well. Examples are known from both shallow and deep water settings, and may reflect any combination of sediment winnowing, sediment bypass, and sediment starvation (Jenkyns 1971; Wendt \& Aigner 1985; Kidwell 1991a,b; Fels \& Seyfried 1993; Gómez \& Fernández-López 1994).

Condensed deposits are idealized as relatively complete records of prolonged low net sedimentation, but examples vary in completeness (e.g., some subzones from the normal series may be unrepresented; this is a variant of discontinuous time-averaging sensu Fürsich \& Aberhan 1990), in total duration (number of zones condensed), and in the degree of stratigraphic thinning (expressed either as a percentage of normal section thickness, or as a rock accumlation rate, generally $<1 \mathrm{~m}$ per my). In some instances, the input or preservation of fossils is so discontinuous that there is a great discrepancy in the ages of mixed fossils.

The end-member situation where the assemblage is composed entirely of fossils exhumed from much older strata is best categorized as a remanié or lag assemblage, but all gradations exist in the quantities of remanié that may be incorporated into a younger fossil assemblage, and in the agediscrepancy between the remanié and younger fossils. Assemblages condensed (telescoped) via repeated winnowing and erosional truncation may in fact be difficult to distinguish from those mixed with remanié, because some degree of diagenetic modification and stabilization is practically axiomatic for the oldest cohorts to survive timeaveraging via winnowing over such long time scales (e.g., Wendt \& Aigner 1985; Machalski \& Walaszczyk 1987; for this reason, Gómez \& Fernández-López 1994 refer to all reworked specimens as remanié, even if they are the same age as associated fossils). Reconstructing the short-term dynamics of condensation commonly depends upon such sedimentologic and taphonomic evidence, because biostratigraphic evidence alone is often not adequate to distinguish between intervals condensed via episodic winnowing or erosional truncation, and those condensed via a slowdown in pelagic rain, even in highly resolved Cenozoic successions (e.g., Aubrey 1995).

In absolute terms, biostratigraphically condensed assemblages require evolutionarily long periods of time for formation. This might comprise at minimum a few hundreds of thousands of years for geological records characterized by rapidly evolving or diverse groups with very short biozones, and several million years for records containing slowly evolving groups.

\section{DETERMINING THE DURATION AND DYNAMICS OF TIME-AVERAGING IN MODERN DEATH ASSEMBLAGES}

In modern death assemblages, the duration of timeaveraging - that is the difference between the time of death of the oldest individual in the assemblage and the time of death of the youngest - can be determined by direct dating of shells. Both radiocarbon (for deposits younger than $\sim 40,000$ years) and amino-acid racemization (for deposits as old as 1.5 million years in mid-latitudes) are appropriate (see Flessa 1993 for this specific application).

Few studies have addressed this problem directly, but these yield consistent results for bivalves (Wehmiller et al. 1988, 1995; Nelson et al. 1988; Flessa et al. 1993; Martin et al. 1996; Meldahl et al. 1997): shell ages range up to several thousand years in actively forming death assemblages on beaches, tidal flats, and nearshore subtidal habitats $(<10 \mathrm{~m})$, and can be several thousands to a few tens of thousands of years old on the open shelf, where conditions of low net sedimentation among other factors promote thin shelly records of marine transgression. A compilation of 734 published radiocarbon dates from 276 localities produces similar patterns: median maximum ages of 1,250 years in nearshore localities $(<10 \mathrm{~m}$ depth) and 9,190 years in shelf localities (Flessa \& Kowalewski 1994) (Fig. 2). These constitute estimates for within-habitat time-averaging in beach and nearshore settings and for within-habitat time-averaged and environmental condensed assemblages on the open shelf, and indicate that such long periods of time-averaging are typical rather than unusual for modern molluscan assemblages. These coincide with estimates using independent indirect methods (described above, Fig. 1), 

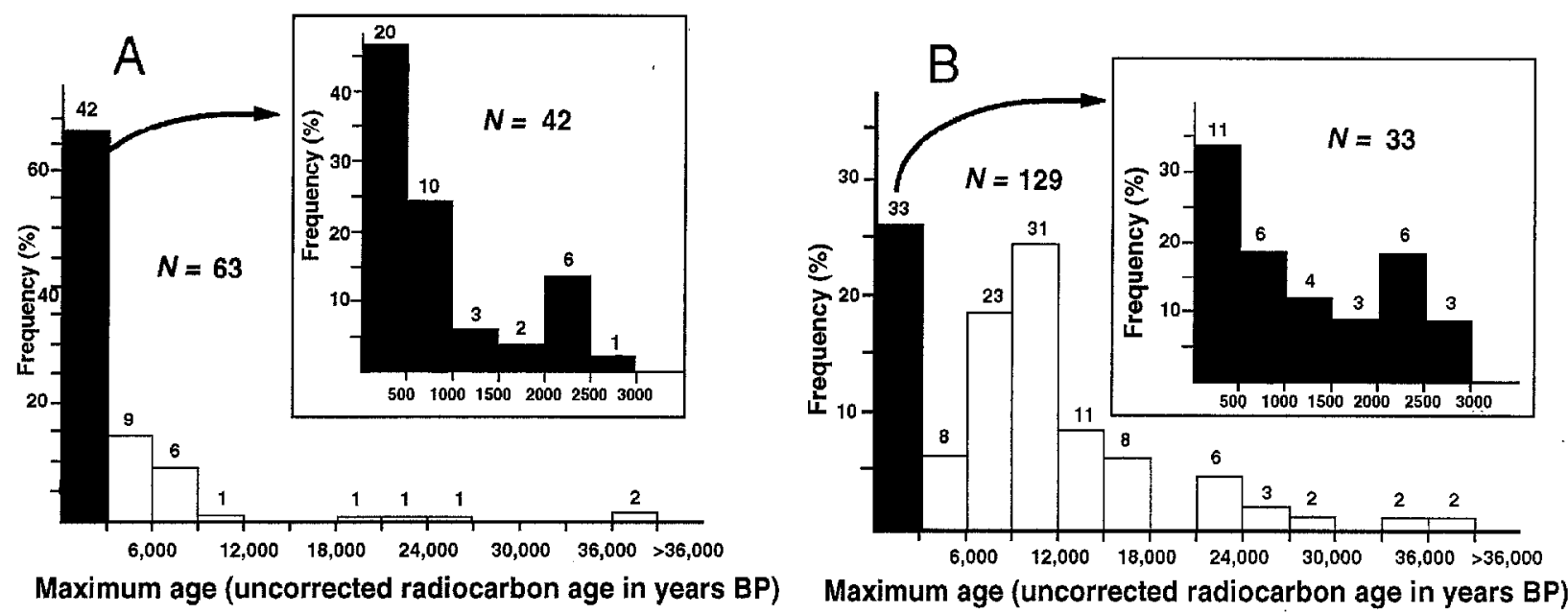

FIGURE 2 - Frequency distribution of the maximum ages of shells in actively accumulating molluscan death assemblages in (A) nearshore localities (median maximum age $=1,250$ years) and (B) shelf localities (median maximum age $=9,190$ years), based on a review of the radiocarbon literature (reprinted from Flessa \& Kowalewski 1994). Number above bar indicates absolute frequency in that age class. These data document the durability and potential of shells to be time-averaged over thousands to a few tens of thousands of years, and confirm the indirect reasoning used to estimate absolute scales of time-averaging in the fossil record (compare with age estimates for within-habitat time-averaging and énvironmental condensation in the same environments in Fig. 1). Distribution de fréquence des âges maxima des coquilles dans des assemblages post-mortem d'accumulation active de mollusques (A) dans des sites littoraux (âge médian maximum $=1250$ ans) et (B) dans des sites de plate-forme (âge médian maximum $=9190$ ans), basée sur une revue de la littérature du radiocarbone (repris de Flessa \& Kowalewski 1994). Le nombre au-dessus de chaque barre indique la fréquence absolue dans chaque classe d'âge. Ces données montrent la durée possible et la capacité des coquilles d'avoir une durée d'accumulation de quelques milliers à quelques dizaines de milliers d'années, elles confirment le raisonnement indirect utilisé pour évaluer des échelles absolues d'estimation de la durée d'accumulation dans le registre fossile (à comparer avec les évaluations d'âge pour l'estimation de la durée d'accumulation dans un habitat et à la condensation environnementale dans les mêmes milieux de la Fig. 1).

and thus confirm the reliability of paleontologic/geologic reasoning for the fossil record (Flessa \& Kowalewski 1994; Meldahl et al. 1997).

The strongly right-skewed frequency distributions for mollusk shells from modern death assemblages ("hollow curves" in Fig. 2) indicate that, although assemblages contain some very old shells, most dated shells are quite young (a few hundred years or less). This does not prove but is certainly consistent with the idea that individual cohorts of dead shells "fade" in numbers during the period of timeaveraging, so that the final assemblage sampled by the paleontologist is dominated by shells of relatively young vintage. The quite good agreement of species relative abundances in death assemblages with that in the local live community is also consistent with this model of how the compositions of assemblages develop over the course of time-averaging (Kidwell \& Flessa 1995). This would be very good news for paleobiologists if generally true, because it suggests that time-averaging largely adds a few old shells to mixed assemblages (ghosts of old generations), rather than thoroughly and equally admixing shells of diverse ages.

As discussed by Flessa \& Kowalewski (1994), the long durations of time-averaging documented by radiocarbon and amino-acid racemization do not contradict observations and inferences of rapid shell destruction in modern environments (e.g. Peterson 1976; Cummins et al. 1986; Davies et al. 1989), only that those high rates do not remove all shell material from the record before it reaches a depth of permanent burial. Moreover, the very short "half-lives" calculated by Cummins et al. (1986) for mollusk shells in Texas lagoons (e.g. 40307 days for half of all shell input to have disappeared) applied only to very small specimens (adult and post-larval shells less than a few $\mathrm{mm}$ long); half-lives were "immeasurably long" for all others, and these surviving elements are those dated in other studies of death assemblages. The model preferred by actualists to explain long periods of timeaveraging of mollusk shells -i.e., that intermittent burial protects shells from attack for some or much of the period of time-averaging (Driscoll 1970; Seilacher 1985; Powell et al. 1989; Flessa et al. 1993)- is identical to that inferred by paleontologists to explain time-averaged and condensed assemblages in the fossil record (Jenkyns 1971; Wendt \& Aigner 1985; Kidwell 1982, 1989; Kidwell \& Aigner 1985), further corroborating the power of the indirect methods that paleontologists must use to evaluate the pre-Quaternary record. 


\section{RECOGNIZING TIME-AVERAGING IN FOSSIL ASSEMBLAGES}

For many paleontologic studies, being able to evaluate the relative scale of time-averaging in fossil assemblages is adequate for the paleobiologic question at hand, but in other instances an absolute estimate of duration is desirable, and both types of analysis are discussed here. Absolute estimates should not be assumed to be superior to strictly relative rankings. For example, a thousand years of time-averaging in one setting may result in only within-habitat time-averaging, whereas in another instance it may involve environmental condensation. Those two assemblages would present very different kinds of records for paleobiologic analysis.

\section{RECOGNIZING RELATIVE SCALES OF TIME- AVERAGING}

Identifying the relative scale of time-averaging is largely a process of elimination. It requires multiple lines of taphonomic, sedimentologic, stratigraphic, and paleontologic evidence - no single type of evidence is usually sufficient (Fig. 3).

Step 1. Test the given assemblage for census attributes. Sedimentologic features such as mud-drapes, graded deposition, an unusual concentration or diversity of rapidly precipitated authigenic minerals, and the restriction of fossils to a single bedding plane are common ancillary lines of evidence (see Brett \& Seilacher 1991; Brett \& Baird 1993), but the primary evidence for mass death and rapid permanent burial will be taphonomic. Classic features include a low proportion of broken specimens, a high proportion of articulated specimens, and some or many specimens in life positions. However, the absence of specimens in life-position does not necessarily mean that the assemblage is not a census-type snapshot. Epifaunal organisms are less likely to be preserved in life-positions than infaunal individuals even under the most benign circumstances, and some censuses are created by en masse transport of organisms into an exotic environment of death and burial, so that none are in life-positions (e.g., Burgess Shale). In general, however, there should be minimal evidence for post-mortem modification of elements other than possible rotation or transport, and in some instances there might be superb preservation of soft-tissues as well as of biomineralized skeletal elements.

Step 2. If a census origin can be eliminated, then the next step is to test for the opposite extreme of biostratigraphic condensation. By definition, biostratigraphically condensed assemblages contain taxa that ordinarily have mutually exclusive chronostratigraphic ranges. The taphonomic condition of the fossils (degree of articulation,

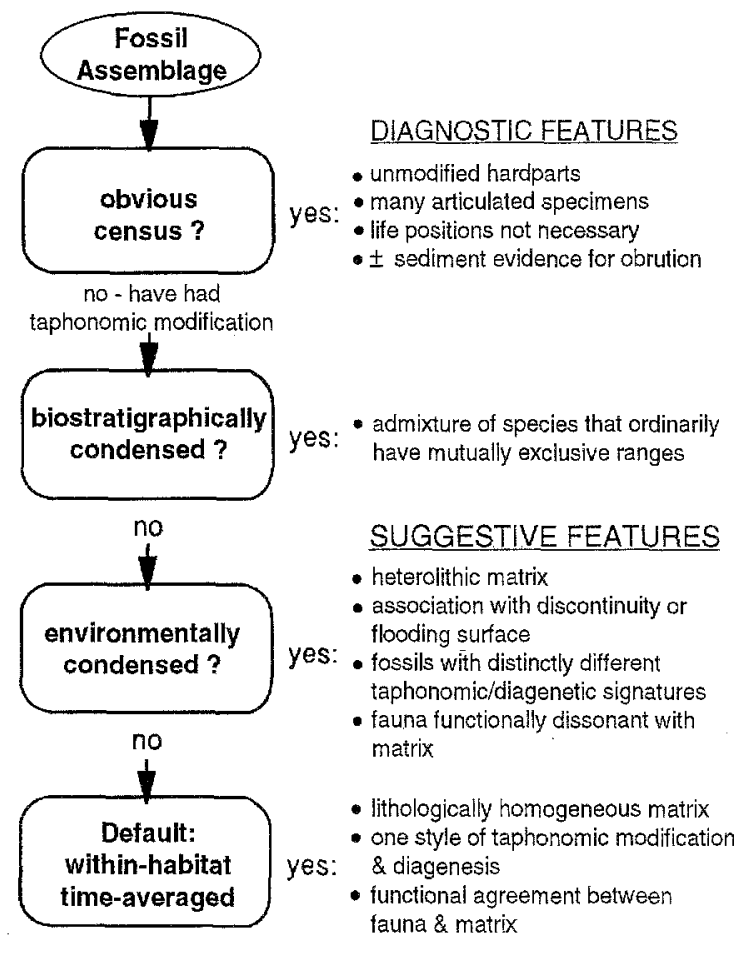

FIGURE 3 - Steps in interpreting the relative scale of time-averaging within a fossil assemblage. Etapes dans l'interprétation de l'échelle relative de l'estimation de la durée d'accumulation dans un assemblage fossile.

wear, diagenetic alteration) is not a consideration in establishing biostratigraphic condensation, although it may illuminate the conditions under which condensation occurred.

Step 3. Most fossil assemblages are neither censuses nor biostratigraphically condensed, but fall between these extremes. To discriminate within this part of the spectrum, the best strategy in my experience has been first to test for evidence of environmental condensation. Reasons to suspect environmental condensation include (adapted from Fürsich 1978; Kidwell 1993a):

a, discontinuity surfaces that extend through the stratigraphic interval containing the assemblage. These can be present even within very thin "beds", and can be quite subtle lithologically or even partly obliterated by burrowing and bioturbation (a particular problem in the post-Paleozoic record); the host sediment may be heterolithic; $\mathbf{b}$, fossils with disparate qualities of preservation, so that the taphonomic character of the total assemblage would be described as bimodal or polymodal, rather than simply a range in grades from specimen to specimen;

c, up-section variation in the quality of preservation consistent with change (or a series of changes) in water energy, oxygenation, depositio- 
nal tempo, etc. Excluded are simple up-section shifts in fossil condition linked to single-event phenomena such as graded bedding;

d, association of the assemblage with a major stratigraphic discontinuity. Subsets of fossils may be filled with sediment that differs from the surrounding matrix, or may have a different style of skeletal preservation, indicating reworking from older strata (including strata not otherwise preserved at the discontinuity);

e, association with an interval or surface of sharp deepening or shallowing, as inferred from lithologic features; and,

f, ecologically disparate faunas admixed within bed. Ecological disparity might be recognized by reference to (i) the ecological tolerances of living descendants, (ii) functional analysis (e.g., any mixture of soup-, firm-, shell-, and hard-ground dwelling forms), or (iii) species co-occurrences that diverge from those that are typical for stereotypic biofacies of the same geologic age and province. In general, this ecological approach is least desirable because of the potential to become circular. It should be used to corroborate an evaluation suggested by taphonomic, sedimentologic, or stratigraphic evidence, rather than used alone.

Also suspect are assemblages from stratigraphic intervals that are demonstrably thinner than coeval strata, for example based on the stratigraphic convergence of marker beds or biozone boundaries (i.e. stratigraphically condensed intervals). Thinning may occur over paleohighs (because of local starvation or enhanced winnowing) but also in paleolows (siliciclastic starvation or suppressed rates of carbonate production), on bathymetric "plateaus" (bypassing in a toplap situation), and on slopes (focussing winnowing or bypassing), and thus is not limited to a particular water depth or phase of basin development. Environmentally condensed assemblages are not limited to stratigraphically condensed intervals, but these are suspect records (see discussion in section "Variation through depositional sequences").

The most difficult situations are where fossils from successive environments have become thoroughly admixed, either because of bioturbation or because of storm or other physical reworking (burial-exhumation cycles). This homogenization obscures or obliterates sedimentologic and stratigraphic evidence of a complex history of fossil accumulation, and in that way also removes the most conservative basis available to the paleontologist for dissecting the assemblage into a series of higher resolution sub-assemblages.

Step 4. In the absence of evidence for census, biostratigraphic condensation, or environmental condensation, the assemblage would be assumed to be within-habitat time-averaged, i.e. consisting of multiple generations from a single indigenous community. This is a default category. Positive evidence consistent with, but not proof of, withinhabitat time-averaging includes:

a, lithologically homogeneous matrix;

b, functional agreement between taxa and matrix; and,

c, single style of preservation among taxa of similar construction, or continuous range in quality, including diagenesis.

General Caveats. Several kinds of error will occur using these guidelines. For example, the most unambiguous census assemblages come from highly stressed environments where both colonization and death are highly pulsed; black shales and other intermittently anoxic settings are good examples. In other settings, however, some true census assemblages will be erroneously categorized as within-habitat time-averaged, especially where bioturbation might have disrupted and disarticulated specimens without admixing other generations of dead material. It is difficult to see how this kind of error could be avoided, but fortunately it is a conservative one.

These four categories subdivide a continuum of time-averaging, and so many intergradations are possible. For example, if a catastrophically censused community occupied a seafloor that contained any quantity of organic remains from previous generations (i.e., if the census was preceded by a period of attritional mortality or a background of exotic input), then the taphonomic signature of the census will be diluted accordingly. The assemblage is actually a kind of hybrid.

Some environmentally condensed assemblages will probably be erroneously categorized as withinhabitat time-averaged, but the confusion should primarily concern examples where condensation is of a very fine-scale (for example, situations of taphonomic feedback where dead shell input influences the living community, or situations where community states fluctuate rapidly due to highly variable environmental conditions, such as common in closed lagoons, small lakes, and silled basins). The most practical approach is to take particular care in evaluating: (a) assemblages from densely packed shellbeds of all scales, since these commonly record multiple rather than single events of shell reworking; (b) assemblages from facies of high-stress environments as listed above, where the environment is recognized from independent sedimentologic and stratigraphic evidence; and (c) assemblages that mantle or immediately underlie stratigraphically significant discontinuity surfaces (e.g., flooding surfaces, sequence boundaries, mid-sequence condensed intervals, etc). 
ESTIMATING ABSOLUTE DURATION

\section{IN FOSSIL ASSEMBLAGES}

There are several approaches to estimating the number years recorded by particular fossil assemblages, and all should be attempted for concordance.

Use horizons of known age (e.g., biostratigraphic datums, ash beds, sequence boundaries) or the known duration of other phenomena (e.g., average durations of species) to estimate the time value of the larger stratigraphic interval that includes the assemblage of interest. This yields a maximum possible duration for time-averaging.

Estimate the time required to deposit the bed that hosts the assemblage, reasoning from its sedimentology. This is the original reasoning of Walker \& Bambach (1971), and is especially useful for analyzing the duration of time-averaging within dense shell concentrations (Kidwell 1993a; Brett \& Baird 1993). There are several caveats for coquinas - for example storm beds that accumulate in days may nonetheless include time-averaged shells exhumed from the seafloor - but these are common sensical. In a few instances, time-averaging may have operated over a shorter period than required to deposit the host bed (e.g., infaunal assemblages that penetrate only the upper part of a unit, down from a capping discontinuity). But in most instances, the time required to accumulate the host bed is a minimum period for time-averaging of the fossil assemblage that it contains.

Extrapolate from modern analogs. The assumption of uniformitarianism is probably acceptable for the younger fossil record (e.g., Cretaceous and Cenozoic): if the sedimentary deposit that contains the fossils is known in modern settings to be characterized by low time-averaging, then the fossil assemblage might be inferred to have comparable resolution. Absolute durations of time-averaging (see above) might even be extrapolated for molluscan assemblages of these ages. Some ancient depositional systems, however, and many extinct groups, have few or no analogs in the modern world, and many extant groups of marine organisms with important fossil records have received little actualistic examination (e.g., scales of timeaveraging in modern death assemblages of bryozoans, brachiopods, crustaceans, corals, coralline algae, larger forams). For these, the best strategy at present might be to apply the broad estimates of absolute time in Figure 1, once the relative scale of time-averaging in the fossil assemblage has been established (as discussed above). I suspect, however, that these absolute estimates will be maximum possible durations of time-averaging for other taxa: bivalve shells seem to be exceptionally durable hardparts among marine macrobenthos
(Kidwell \& Flessa 1993; and see discussion below).

Estimate the time inherent in the state of fossil preservation. This is a logical approach, since a shell's condition should only worsen with increasing exposure to taphonomic processes after death. However, attempts to calibrate such a "taphonomic clock" (Kidwell 1993a) in absolute years are yielding mixed results, and thus the method can not yet be recommended (discussed below).

\section{EXAMPLES OF ANALYSIS}

Applying these approaches (methods 1-3 above) to benthic assemblages in the Miocene of Maryland, Kidwell (1982) estimated tens to hundreds or a few thousands of years for assemblages associated with bedding planes or contained within "minor simple" shell beds (concentrations smaller in physical dimensions than sparsely fossiliferous facies in the section, and having internally homogeneous or monotonic change in matrix and biostratinomy). These contrasted with "major complex" shell beds (laterally more extensive than other facies or divisible into facies, and having complex internal stratigraphies), which provided thin (stratigraphically condensed) records of transgressive marine facies. The fossils in major complex deposits clearly recorded more time than a simple time-averaged assemblage in the sense of Walker \& Bambach (1971) since each major shellbed was environmentally condensed, and recorded more time than a single "minor simple" shell bed since many of these were amalgamated or stacked within a single major complex bed. Each major complex accumulation lay within a single planktonic foraminiferal zone $(\sim 0.5-$ $1.0 \mathrm{my}$ each) and comprised only part of the total range of most of its molluscan species (average duration of North American Neogene species is 1-10 my). Each complex shell bed thus must have formed over a period shorter than $\sim 0.5 \mathrm{my}$, but probably longer than $10^{2}$ years; $10^{3}$ to $10^{4}$ years were estimated. This estimate was corroborated by analogy with radiocarbon-dated shell-rich sands that have formed on modern shelves during the past 18,000 years of marine transgression.

Brandt (1985) and Parsons et al. (1988) used similar reasoning for assemblages in Ordovician and Devonian strata, producing estimates of tens to thousands of years for assemblages ranging from simple to condensed shell beds (and see estimates in Brett \& Baird 1993).

\section{IS THERE A TAPHONOMIC CLOCK?}

We intuitively know that taphonomic damage is a function of time as well as environment after death, as the condition of a carcass can only dete- 
riorate. Shell condition has been used since the earliest days of marine taphonomy to distinguish census from non-census assemblages (e.g., Johnson 1960), but the extent to which differences in the degree of skeletal deterioration can be used to differentiate among the various scales of timeaveraging is not clear, nor is it clear that shell condition can be used to calibrate the duration of time-averaging in absolute years. After all, destructive conditions do not always operate continuously in a given environment (e.g., seasonality and longer variation in water energy, bioturbation, and corrosive porewaters), nor are individual shells necessarily exposed continuously to destructive processes (e.g., intermittent burial or emersion, development of protective overgrowths). Damage thus will not necessarily accrue in a steady, clock-like manner after death.

Is there in fact a taphonomic clock for shell agesince-death in modern assemblages, such as might then be applied to the fossil record? The answer has consequences for two practical issues: (1) whether taphonomic damage can be used to reassign individual shells into their original generational cohorts, allowing the investigator to "unmix" time-averaged assemblages; and (2) whether the overall condition of the assemblage (as opposed to that of individual shells) can be used to estimate the absolute scale of time-averaging for the total assemblage.

These issues have now been tested in a number of shallow marine settings (Powell \& Davies 1990; Flessa et al. 1993; Wehmiller et al. 1995; Martin et al. 1996; Meldahl et al. 1997). The types of damage used to rank shell deterioration include disarticulation, fragmentation, epibiont encrustation, abrasion, corrosion, bioerosion (original criteria of Johnson 1960), and loss of color, surface glossiness, and organic coats (Powell \& Davies 1990). These studies have found only a weak relationship bet-

FIGURE 4 - Frequency distribution of shell ages in actively forming bivalve death assemblages from five intertidal to shallow subtidal environments in the Gulf of California, documenting time-averaging over many hundreds to a few thousands of years (A-E; from Meldahl et al. 1997). Although the oldest shells in each time-averaged assemblage are typically highly altered (Grade 4), the youngest shells range in condition from unaltered (Grade 1) to moderately (Grade 3) or high altered. Post-mortem damage accrues rapidly but erratically, and thus is a poor clock of an individual shell's age-since-death. Distribution de fréquence des âges des coquilles dans des assem. blages post-mortem en formation active de bivalves dans cinq environnements de l'intertidal au subtidal peu profond du Golfe de Californie, montrant la durée d'accumulation de plusieurs centaines à quelques milliers d'années (A-E : d'après Meldahl et al. 1997). Quoique les plus anciennes coquilles dans chaque assemblage de durée d'accumulation évaluée soient typiquement très altérées (Grade 4), les coquilles les plus récentes se répartissent d'inaltérées (Grade 1) à modérément (Grade 3) et hautement altérées. Les dommages post-mortem s'accroissent rapidement mais de façon stochastique, cela constitue donc une horloge imprécise de l'âge individuel des coquilles depuis la mort.

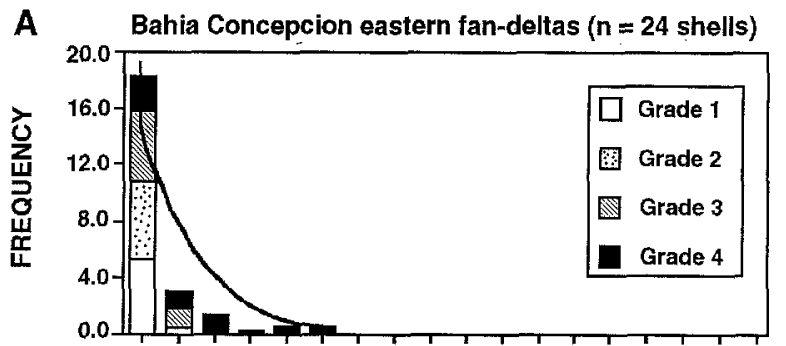

B

Bahia Concepcion eastern fan-deltas ( $n=24$ shells)
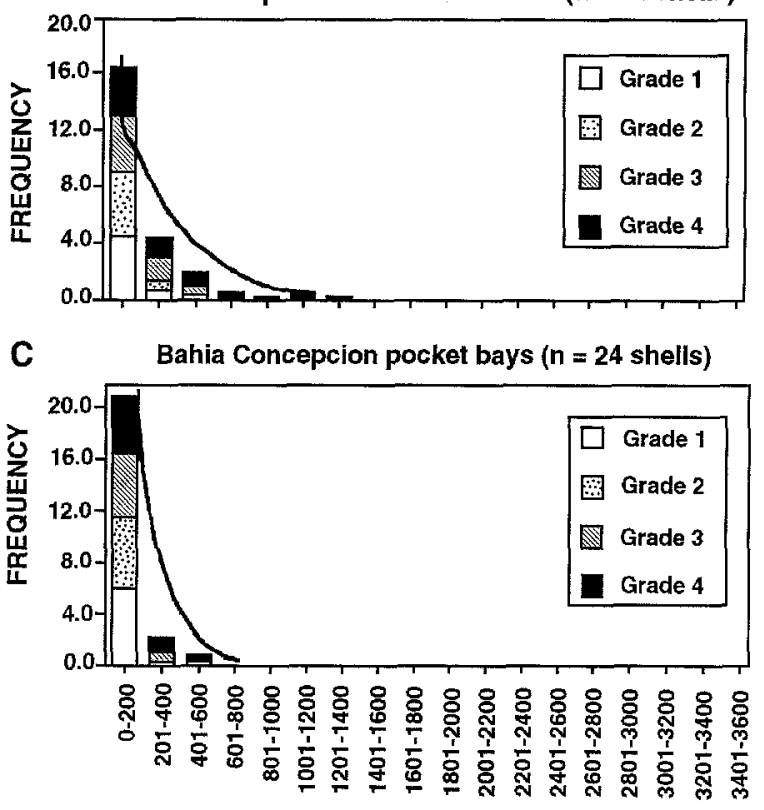

SHELL AGE (calendar years before 1950)

D

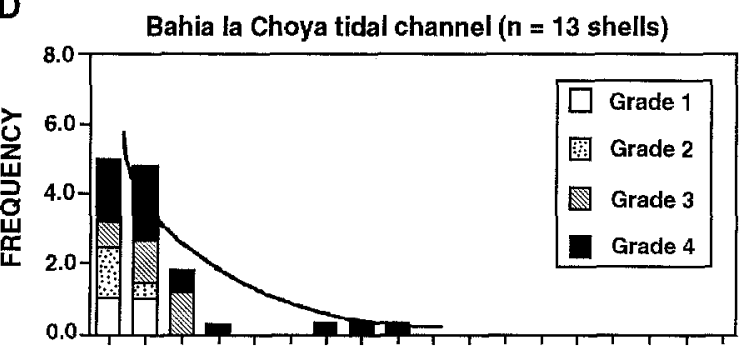

E

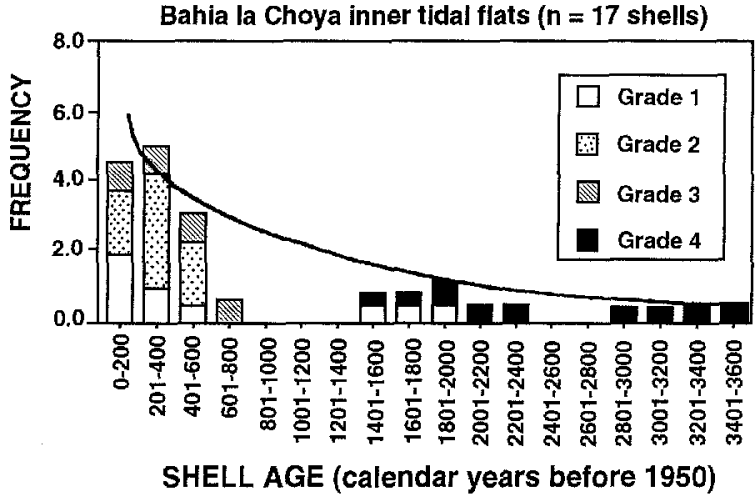




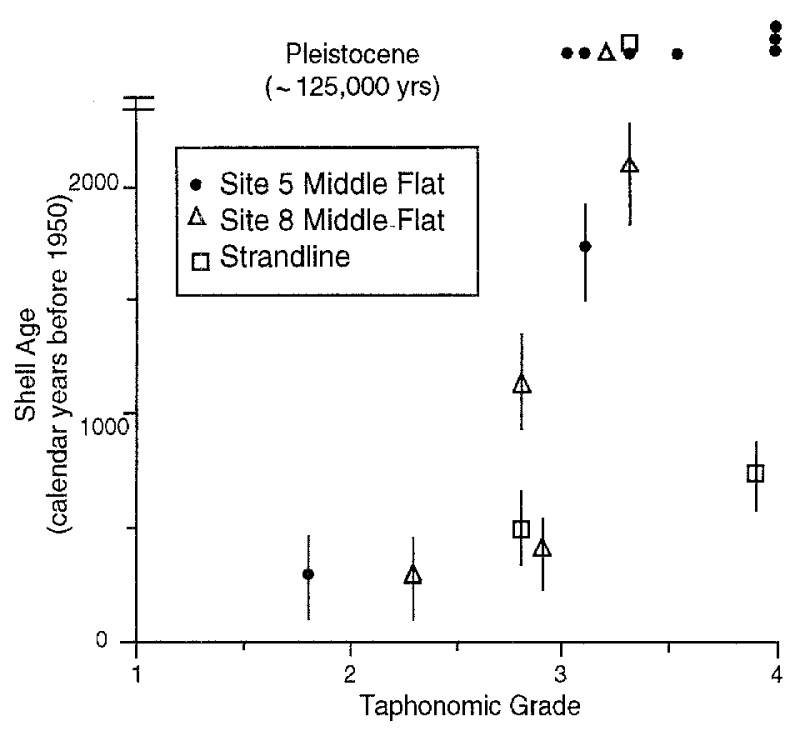

FIGURE 5 - Relationship between shell age and taphonomic condition for bivalves from three actively forming death assemblages from intertidal Gulf of California (within a few hundred meters of area $E$ of Fig. 4) (data replotted from Martin et al. 1996). The youngest shells are a few hundred years old and are in the best condition (Grade 2-3); older shells are in comparable or worse condition (Grade 3 or 4 ) but there is no consistent deterioration with age, even when Pleistocene specimens are considered ( 125,000 years old). Each shell was dated by both amino acid racemization and radiocarbon methods. The wide range of ages of shells exhibiting Grade 3 damage demonstrate the difficulty in using shell condition to estimate age-since-death. Relations entre l'âge de la coquille et les conditions taphonomiques pour les bivalves d'après trois assemblages post-mortem se formant activement en zone intertidale dans le Golfe de Californie (sur quelques centaines de mètres de l'aire $E$ de la Fig. 4) (données reprises de Martin et al. 1996). Les coquilles les plus récentes ont quelques centaines d'années et sont en bon état de conservation (Grades 2-3); les coquilles plus anciennes sont de conservation comparable ou plus mauvaise (Grades 3 ou 4) mais il n'y a pas de détérioration en relation avec l'âge, même quand on considère des spécimens du Pléistocène (- 125000 ans). Chaque coquille a été datée par les deux méthodes de la racémisation des aminoacides et du radiocarbone. La large distribution des âges des coquilles présentant des dommages du Grade 3 souligne la difficulté d'interprétation de l'état des coquilles pour en estimer l'âge depuis la mort.

ween shell age (time-since-death) and taphonomic condition ("grade") within the first few hundreds or thousands of years after death. Color and surface glossiness are the only exceptions (and see Wilson 1988; Van Der Valk 1991), but neither of these is likely to survive later diagenesis. The oldest shells in an assemblage are generally moderately to highly altered, but many younger shells may be in equally poor condition (Figs. 4,5). Thus, using the condition of a shell to reconstruct its age relative to others in the assemblage is not yet demonstrably reliable for assemblages time-averaged over periods as short as a few centuries or millennia (Flessa 1993). The presumption is that burial stops the clock of shell damage, and intervals of exhumation and exposure on the seafloor for individual shells are too erratic over periods of only a few millenia for successively aged subpopulations of shells to have acquired distinctive levels of taphonomic damage (op cit., and Seilacher 1985). This is consistent with field experiments: shells quickly become damaged when exposed continuously to destructive processes on the seafloor, but acquire damage more erratically and thus slowly when permitted to undergo natural burial/exhumation cycles (e.g., tethered-shell experiments of Driscoll 1970; Best \& Kidwell 1995).

Several workers have reported that Pleistocene shells can be readily distinguished from Recent shells in modern transgressive beach and nearshore assemblages on the basis of shell damage, indicating that shell condition can be sensitive to the period of time-averaging when shell subpopulations differ in age by many tens of thousands to hundreds of thousands of years (Frey \& Howard 1986; Henderson \& Frey 1986; Wehmiller \& York 1992; Wehmiller et al. 1995; Flessa 1993). Here again, however, the distinction is based on shell color (blackening) and/or polishing, which are unlikely to be preserved in the older stratigraphic record; fragmentation varies among sites depending upon energy levels, and is thus unreliable. In one instance (intertidal northern Gulf of California), specimens reworked from Pleistocene beachrock are characterized by lack of color, chalky surface texture, and bits of adhering cemented matrix (Flessa 1993), but nonetheless are not significantly different in condition from shells that are only one thousand years old (Martin et al. 1996) (Fig. 5). The evidence that a taphonomic clock operates over these longer time-periods is thus still weak.

Although the relationship between the scale of time-averaging and the condition of any individual shell is weak, the overall condition of an assemblage might still degrade consistently with elapsed time. The overall condition of an assemblage can be quantified several ways (average shell condition, modal shell condition, frequency distribution of shell condition) and can be based on any subset of possible taphonomic features (disarticulation, fragmentation, glossiness, etc) (e.g., Brandt 1989; Davies et al. 1989; Flessa et al. 1993; Kowalewski et al. 1995). Actualistic studies indicate, however, that, here again, there is no strong relationship between assemblage grade and years of time-averaging within the first few thousands of years of time-averaging (Flessa 1993; Martin et al. 1996; Meldahl et al. 1997), notwithstanding the strong tendency for the oldest shells to be in poor condition (Fig. 4). The weakness in the relationship might be in part an artefact of environmental differences among the 


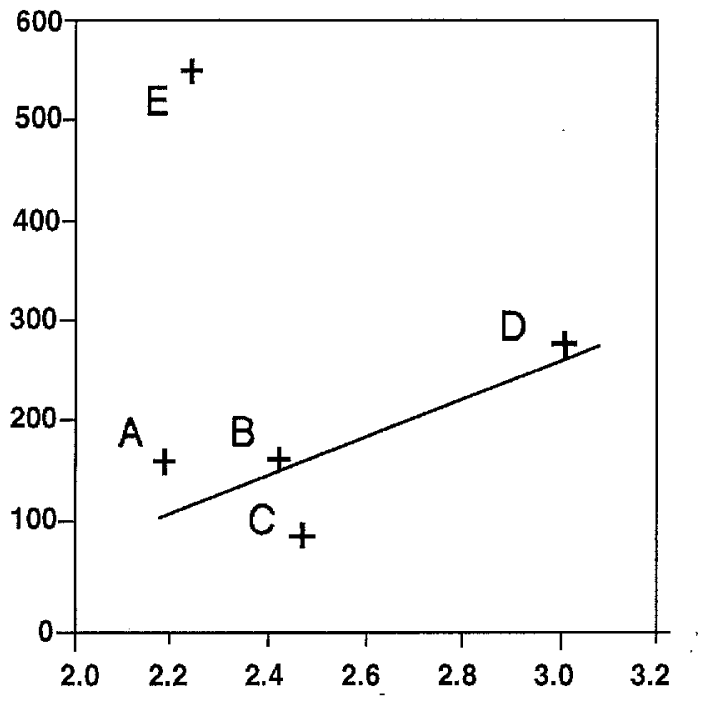

\section{Average Taphonomic Grade}

increasing taphonomic alteration

FIGURE 6 - Relationship between scale of time-averaging and average taphonomic grade for actively forming bivalve death assemblages, based on data from Fig. 4 (reprinted from Meldahl et al. 1997). Scale of time-averaging is expressed as shell halflife, calculated from the curves in Fig. 4. Assemblages A-D are all from subtidal settings, and, although the regression line is not significant, a relationship between damage and time-averaging is suggested. Outlying assemblage $\mathrm{E}$ shows much less damage than expected for the duration of time-averaging, but it is from an upper intertidal setting where diurnal emergence of shells slows taphonomic attack. Relations entre l'échelle d'estimation de la durée d'accumulation et le grade taphonomique moyen pour les assemblages post-mortem de bivalves se formant activement, d'après les données de la Fig. 4 (repris de Meldahl et al. 1997). L'échelle de l'estimation de la durée d'accumulation est exprimée comme la moitié de la durée de vie de la coquille, calculée d'après les courbes de la Fig. 4. Les assemblages A-D proviennent tous de sites subtidaux et, quoique la droite de régression ne soit pas significative, une relation entre les dommages et l'évaluation de vie moyenne est suggérée. L'assemblage isolé $E$ montre beaucoup moins de dommages qu'on ne l'attend d'après la durée d'accumulation, mais il provient d'un site de l'intertidal supérieur où l'émersion quotidienne des coquilles réduit les dégâts taphonomiques.

assemblages tested so far. The large age-calibrated dataset that Meldahl et al. (1997) are developing for intertidal and shallow subtidal assemblages from the subtropical Gulf of California is providing important new information on the possible effect of environment on taphonomic clocks (Fig. 6). They have found, for example, that the average quality of shell preservation declines with increasing duration of time-averaging for a series of four lower intertidal to shallow-subtidal assemblages, but that an upper intertidal assemblage with far greater time-averaging has very low damage, apparently because emergence during low tides stops the taphonomic clock as effectively as shallow burial in subtidal settings.

Insights from the stratigraphic record are generally consistent with this provisional conclusion about modern molluscan death assemblages: the overall condition of the assemblage seems to be as strongly or even more strongly linked to the environment of accumulation (as originally implied by Johnson 1960), and particularly the short-term burial/exhumation dynamics of shells, than it is to the duration of time-averaging. The most common signature in all types of time-averaged assemblages is a mixture of shells exhibiting a full range of physical and biogenic damage. Kidwell \& Aigner (1985), for example, found shells in all stages of post-mortem disintegration, including articulated and disarticulated, whole and fragmented, pristine and biocorroded, sharp and abraded, from a series of environmentally condensed hiatal deposits where complex accumulation histories could be inferred on independent sedimentologic evidence. This makes sense, given that by definition new material is continually added to an assemblage during time-averaging, so that while early cohorts may have degraded to taxonomically unidentifiable debris, the assemblage should include shells in all conditions up to perfectly fresh (and see same argument in Fürsich \& Flessa 1991 for modern assemblages). The spectrum of damage does not broaden appreciably in biostratigraphically condensed assemblages, nor is it notably narrower for within-habitat time-averaged assemblages, suggesting that this mixed condition develops quickly and persists even through long periods of time-averaging (and see Fürsich \& Aberhan 1990; Fürsich \& Oschmann 1993; Kidwell 1993a). Taphonomic grade based on biostratinomic (pre-burial) criteria thus seems reliable only for distinguishing census assemblages from all other time-averaged assemblages, and not for discriminating among time-averaged assemblages formed over different time-scales.

The stratigraphic record suggests that other taphonomic features do begin to accrue with progressive time-averaging, and would thus be useful for distinguishing among these longer scales of time-averaging. These features are (a) diagenetic heterogeneity in the assemblage itself and (b) microstratigraphic complexity in the sedimentary interval that hosts the assemblage (Kidwell 1993a; Brett \& Baird 1993). For example, condensed assemblages commonly contain mixtures of original shell material, variously replaced shells, and steinkerns. Not all condensed fossil assemblages have a mixed diagenetic signature: many consist entirely of well-preserved aragonitic and calcitic shells. However, I have never encountered 
extreme diagenetic heterogeneity in skeletal assemblages that lack independent evidence of condensation or association with a surface of significant submarine erosion: for example, such heterogeneity is not associated with parasequence- and smaller-scale discontinuity surfaces (see also Holland 1993). Diagenetic heterogeneity appears to be a condition associated with assemblages in which fossils differ in age by many tens of thousandls to hundreds of thousands or more years, at least in siliciclastic records.

Fine-scale complexity in the bedding of skeletal concentrations ("microstratigraphic complexity") also appears to be related to the time-scale of accumulation rather than to the environment of accumulation alone (Kidwell 1991a, 1993a). Minor discontinuity surfaces that cut through stratigraphically condensed shell beds typically are a mixture of types (including scours, burrowed firmgrounds, hardgrounds) and/or form a complexly anastomosing network of surfaces in cross-sectional view (i.e., split and reconverge laterally). This contrasts with the minor surfaces that occur in non-condensed assemblages, which are usually of a single type, or trend up-section from one type to another. It appears that the more prolonged the period of condensation, then the more varied or random the mix of internal discontinuity types (e.g., biostratigraphically condensed intervals and remanié-containing lags, as contrasted with environmentally condensed intervals, as contrasted with within-habitat time-averaged assemblages).

These alternative metrics for a taphonomic clock could be tested in modern environments using amino-acid racemization, which can date individuals shells back to $-1.5 \mathrm{Ma}$. An initial test in the stratigraphic record used the relative durations of discontinuity surfaces to independently rank scales of time-averaging in associated fossil assemblages, whose taphonomic grade and other features could then be determined (Kidwell 1993a, 1993b). Other siliciclastic records and especially carbonate records need examination before the true reliability of these potential clocks will be known.

Thus, in evaluating the time-resolution of fossil assemblages, a broad and strongly geological approach is the most powerful one. The target assemblage should be evaluated not only in terms of shell condition (i.e., Johnson's criteria) but also in terms of its diagenesis, sedimentology (including bedding style), and larger stratigraphic context, as these latter features appear to be the most informative.

\section{OTHER UNCERTAINTIES AND NEW DIRECTIONS}

\section{SCALES OF TIME-AVERAGING FOR OTHER MARINE TAXA}

Actualistic studies have provided a wealth of evidence that the skeletons of marine macrobenthos differ significantly in their post-mortem durabilities - owing to such factors as shell size, shape, mineralogy, and microarchitecture - and thus we can be almost certain that their time-averaged assemblages represent different periods of time. Skeletons composed of fragile materials, for example, should degrade so rapidly post-mortem that they might all have disappeared after only a few seasons or years of time-averaging, so that only the simplest forms and briefest duration of within-habitat time-averaging are likely. This, for example, appears to be the situation for organicrich lingulide brachiopod shells, which on modern subtropical intertidal flats disintegrate within a few weeks or months after death (Kowalewski 1996). Extremely rapid post-mortem disintegration probably also explains the very low agreement between living communities and local death assemblages of lightly calcified modern crabs (e.g., Plotnick et al. 1990).

Few such expected differences, however, have been verified or calibrated by direct-dating of naturally occurring death assemblages. This is an important direction for future studies, as it has been very successful for mollusks (references discussed above) and for benthic foraminifera (Martin et al. 1995). Such information would establish just how disparate in time resolution the records of various groups might be, thus allowing more informed comparison of evolutionary and ecological patterns (e.g., one group might appear to support greater morphometric variability per species than another, but if the more variable group was known to be subject to greater timeaveraging per collecting horizon, then its morphometric variability might be inflated taphonomically). This information would also be useful in community-level paleoecology, by indicating whether different taxa within an assemblage might have been subject to significantly different scales of time-averaging (disharmonious time-averaging sensu Kowalewski 1996).

We should not assume that the result of such investigations will be bad news, that is, that the multitaxic assemblage is wildly disharmonic. For example, Martin et al. (1996) and Anderson et al. (1997) both found that Holocene benthic foraminiferal assemblages contain well-preserved specimens several thousands of years old on subtropical 
intertidal flats and open shelves (respectively), comparable to the scale of time-averaging documented in associated molluscan assemblages.

\section{LARGE-SCALE PATTERNS}

\section{Environmental variation in time-averaging}

The variety of processes and circumstances that influence time-averaging suggests that time-resolution for a given taxonomic group may vary significantly among coeval environments. Water energy, frequency of storm reworking, rates of bioerosion, etc. are all known to affect rates of skeletal destruction and can vary dramatically between habitats within a single marine embayment. Moreover, depths of sediment mixing by bioturbators vary both along-shore and offshore (from a few $\mathrm{cm}$ to several meters penetration), as do rates of sediment supply and deposition.

Direct-dating of modern molluscan assemblages indicates that nearshore assemblages are less time-averaged than open shelf assemblages, which are also environmentally condensed due to siliciclastic starvation during Quaternary transgression (see discussion above). But we have virtually no information on how molluscan time-resolution varies among other environments, including open shelves that are aggrading, and so we can only speculate on the basis of modern sedimentation patterns (e.g., Fürsich \& Aberhan 1990; Kidwell \& Bosence 1991; Kidwell \& Flessa 1995).

As a more tangible source of information, the stratigraphic record yields a great variety of patterns (reviewed in Kidwell 1993a) (Fig. 7). For example, the records of coastal lagoons and beach complexes are typically heterogeneous, with a mosaic of census (catastrophic burial, oxygen- and salinity-stress, etc.), within-habitat time-averaged ("normal" bioturbated facies), and environmentally condensed assemblages (in current-generated bioclastic banks, channel lags, bioherms, biogenically graded beds); assemblages dominated by allochthonous shells are also present. The most commonly documented pattern on aggrading open shelves and ramps has three broad depth zones: (1) within-habitat time-averaged assemblages in foreshore and shoreface facies dominated by storm erosion and reworking; (2) a mix of census assemblages interstratified with withinhabitat time-averaged background sediments in the nearshore transition zone, where post-storm deposition is greatest; event-beds of allochthonous fossils are also common here; and (3) within-habitat time-averaged assemblages dominate the offshore zone of distal deposition below maximum storm wavebase; these assemblages take the form of dispersed shells in a fine-grained matrix, mixed by bioturbation and other biological processes; they may also have shelly patches produced by within-habitat taphonomic feedback.

Offshore areas are generally seen as the most common setting for sediment starvation and thus for prolonged time-averaging. The actual record, however, is more complex (reviewed in Kidwell 1991a, 1993a). (1) Unless starvation persists through a significant change in water depth or oxygenation, deep water assemblages will not necessarily be more complex than within-habitat time-averaged due to the great bathymetric ranges of most bathyal and abyssal bio-lithotopes; the absolute duration of time-averaging may be quite long, of course, if sediment accumulation rates are low. (2) In tectonic troughs, deep seafloors may not be starved owing to axial transport of clastics; shallower water parts of the slope and shelf may be starved instead. (3) During rapid transgression (rapid increase in eustatic rise, or increase in tectonic subsidence), broad areas of the shallow shelf may be sediment-starved, producing hiatal concentrations with high potential for environmental condensation; these assemblages may record less absolute time than deep water within-habitat assemblages (1 above). (4) Shallow water hiatal concentrations with envi-
FIGURE 7 - Variation in typical scales of time-averaging across shallow marine facies tracts, and through transgressive-regressive depositional sequences (adapted from figures in Kidwell 1991a, 1991b, 1993a). Variations à des échelles typiques d'évaluation temporelle dans des faciès marins de faible profondeur et des séquences de dépôts transgressives-régressives (adapté de figures de Kidwell 1991a, 1991b, 1993a)

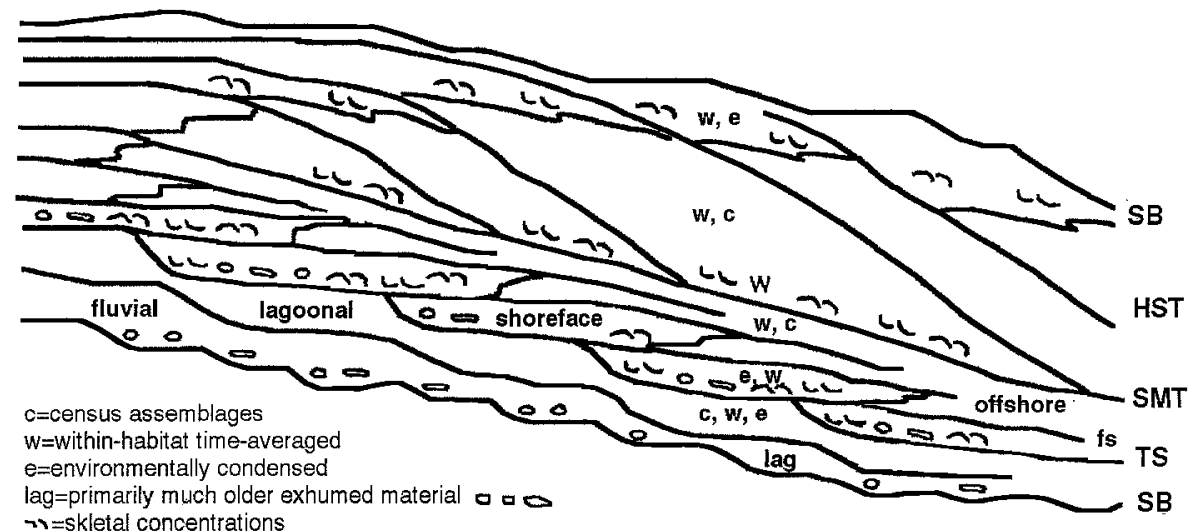


ronmentally condensed assemblages may also form in nearshore areas of intense sediment winnowing and bypassing, and on tectonic and other paleohighs subjected to winnowing and located any distance from the shoreline.

Thus, the record indicates that bathymetric and other environmental trends in time-averaging are highly variable but strongly linked to short- and long-term patterns of sediment accumulation. Areas of highly episodic sediment deposition favor the formation and especially the preservation of censuses, whereas areas of low net rates of seafloor aggradation, either because of repeated winnowing of episodic deposits or because of sediment starvation, favor faunally condensed assemblages of various sorts. Mixing by bioturbation can be superimposed on any of these regimes; its scale and intensity relative to clastic sedimentation are further factors in the preservation of censuses, but mixing depths determined by bioturbators appear to be only a secondary control on time resolution.

\section{Variation through depositional sequences}

Sediment accumulation rates clearly are one factor influencing scales of time-averaging in fossil assemblages, and so time-resolution can be expected to vary systematically (non-randomly) through depositional sequences. Assemblages with the most complex histories of time-averaging are expected to be related to settings of stratigraphic condensation (sensu Jenkyns 1971), that is, where the stratigraphic record is thin relative to coeval sections owing to low net sedimentation. This slow net accumulation may be due to sediment starvation, sediment bypassing, or episodic seafloor winnowing, so that condensed intervals are known from a wide variety of settings, including both shallow and deep water and both proximal and distal locations within basins (Jenkyns 1971; Wendt \& Aigner 1985; Kidwell 1991a,b; Gómez \& Fernández-López 1994; Fels \& Seyfried 1993) (Fig. 7).

Environmentally condensed assemblages are not limited to stratigraphically condensed intervals, but these intervals are good potential sites of environmentally and biostratigraphically condensed assemblages, and thus we expect - and in fact do find - non-random variation in the time-resolution of assemblages through depositional sequences (Kidwell 1991a, 1991b, 1993a, 1993b; Fürsich et al. 1992; Brett \& Baird 1993; Brett 1995; Krawinkel \& Seyfried 1996; Anderson \& McBride 1996). Sequence stratigraphers continue to discover new variants on the anatomy of thirdorder ( 1 my duration) sequences, but some basic elements of the model have been stable, particularly: (1) divisibility into finer-scale, shallowingup parasequences in settings of moderate or grea- ter subsidence; environmental condensation could be associated with each flooding surface, but this appears to be rare in actuality; and (2) the potential for thin, stratigraphically condensed facies wherever time-lines converge (parasequence lapout), most particularly along the leading edges of transgressive surfaces, in distal portions of the basin during maximum transgression, and late in the highstand tract (toplap), although this latter condition is rarely developed or preserved. Assemblages containing remanié depend upon erosional reworking of older strata, and thus are largely limited to sequence boundaries (especially the margins of incised valleys) and transgressive surfaces. Aside from these facies of condensation and erosion, the marine record is dominated by census/snapshot and within-habitat time-averaged assemblages. These non-random distribution patterns clearly have implications for studies on modes of species evolution, on alpha-diversity variation through sealevel fluctuations, and on confidence limits for biostratigraphic zones, since many bed-level datapoints - especially the important collecting horizons immediately below and above stratigraphic hiatuses - may be derived from assemblages that are condensed to some degree (Holland 1995; Marshall 1997).

Although the first-order control on time-resolution through depositional sequences is determined by the mosaic of net sediment accumulation rates the time-space mosaic of erosion, condensation, and "normal" deposition - the short-term dynamics of condensation are also important. Stratigraphic intervals that are thin (condensed) because of winnowing and episodic erosion during accumulation will tend to have discontinuous time-averaging and will commonly include fossils reworked from older layers, whereas intervals that are thin because of little or no sediment supply (sediment starvation) will tend to have continuous time-averaging and little contribution of reworked fossils, at least when these conditions occur in quiet or deep water (Fürsich \& Aberhan 1990; Kidwell 1991a, 1991b; Brett \& Baird 1993; Gómez \& Fernández-López 1994). Other variants include sediment starvation in. relatively high-energy shallow water, such as pertain during initial marine transgression and on some paleohighs; these are characterized by discontinuous time-averaging.

\section{Variation through the Phanerozoic}

Evolution in the nature of skeletons produced as well as in the organisms that influence skeletal preservation (e.g., bioeroders, deep-irrigating bioturbators, duraphagous predators) suggests that scales, absolute durations, biological biases, and taphonomic signatures of time-averaging might also have changed over geologic time. To approach 
this, we compiled a large, field-checked database on the diversity and physical scale of densely packed skeletal concentrations (non-reef), reasoning that these were a function of several factors including skeletal durability, which in turn is a limiting factor on scales of time-averaging (Kidwell \& Brenchley 1996). Data for Ordovician-Silurian, Jurassic, and Neogene strata (and data on Cambrian strata from Li \& Droser 1997) indicate significant expansion over the Phanerozoic in the bioclasticity of the shallow marine record, and suggests that this expansion was driven by evolutionary and ecological changes among shell producers rather than by geological and biological changes in post-mortem environments. With the exception of crinoids, thick bioclastic concentrations appear to be a fundamentally modern phenomenon, with shellbeds expanding in thickness as evolutionarily Modern clades diversified taxonomically in the Mesozoic and Cenozoic and shifted the global biota toward more durable loworganic microstructures, toward occupation of higher-energy habitats, and perhaps toward higher rates of carbonate production.

An increase in the post-mortem durability of skeletons over Phanerozoic time suggests that skeletal assemblages from the younger fossil record are more time-averaged than those from the older fossil record: the more durable the hardparts, the greater the probability that hardparts from successive generations and/or communities at a site will survive short-term reworking events and become mixed into a single time-averaged fossil assemblage. There have always been census assemblages formed by sudden burial or other catastrophic events, but the scope for time-averaging appears to have expanded significantly. The likely discrepancies between early Paleozoic and late Cenozoic scales of time-averaging are difficult to quantify, but could easily be an order-of-magnitude: i.e., within-habitat time-averaging on the order of tens to hundreds of years at maximum for groups such as brachiopods, stenolaemates, and trilobites, rather than hundreds to thousands of years documented for modern bivalves. The most notable exception among Paleozoic metazoans are crinoids, which form thick densely packed bioclastic facies (e.g. Ausich 1997; fusulinid foraminifera are a non-metazoan exception). But crinoids are characterized by a low-organic microstructure that is also unusual for its time, and thus may be a Paleozoic exception that supports rather than refutes the importance of skeletal durability; their assemblages may well have scales of time-averaging more like modern bivalves.

Kidwell \& Brenchley (1996) suggested several ways to test this hypothesis of declining timeresolution, including (1) actualistic investigations of living brachiopods, bryozoans, and crinoids, comparable to the time-resolution studies of living mollusks (see also discussion above), and (2) stratigraphic searches for taphonomic differences in fossil assemblages associated with discontinuity surfaces of similar hiatal duration but different geological age. For example, hiatuses associated with parasequence flooding surfaces are generally shorter than those associated with sequence boundaries, providing a means of ranking the maximum period of time-averaging in the fossil assemblages that mantle such surfaces. Such a survey in post-Paleozoic records (Kidwell 1993b) revealed consistent differences in the kinds of skeletal concentrations associated with different ranks of discontinuity surfaces, implying a different envelop of scales of time-averaging for each rank of surface, but there are as yet no comparable data for the Paleozoic. Phanerozoic declines in other aspects of time resolution in the marine record have also been suggested, related primarily to increasing bioturbation [e.g., apparent declines in the frequency of discrete storm beds and of soft-tissue and fragile skeleton preservation (Brandt 1986; Sepkoski et al. 1991; Allison \& Briggs 1994; Butterfield 1995; Kowalewski \& Flessa 1996)]. Such broad scale changes in the quality of the sampled record are still little explored and exciting directions for future taphonomic research.

Acknowledgments - I am grateful to the editors of Geobios for the invitation to contribute to this anniversary issue, and to David Jablonski for a helpful review. This paper is an outgrowth and updating of notes for a Paleontological Society shortcourse on time resolution in Boston in 1993.

\section{REFERENCES}

Aluison P.A. \& Briggs D.E.G. 1994 - Exceptional fossil record: distribution of soft-tissue preservation through the Phanerozoic. Geology, 21: 527-530.

Anderson L.C. \& McBride R.A. 1996 - Taphonomy and paleoenvironmental evidence of Holocene shell-bed genesis and history on the northestern Gulf of Mexico shelf. Palaios, 11: 532-549.

Anderson L.C., Sen Gupta B.K., McBride R.A. \& Byrnes M.R. 1997 - Reduced seasonality of Holocene climate and pervasive mixing of Holocene marine section, northeastern Gulf of Mexico shelf. Geology, 25: 127-130.

AUBREY M.-P. 1995 - From chronology to stratigraphy: interpreting the Lower and Middle Eocene stratigraphic record in the Atlantic Ocean: 211-274. In Berggren W.A., Kent D.V., Aubry M.-P. \& Hardenbol J. (eds.), Geochronology Time Scales and Global Stratigraphic Correlation. SEPM (Society for Sedimentary Geology) Special Publication, 54.

AusicH W.I. 1997 - Regional encrinites: a vanished lithofacies: 509-519. In BRETT C.E. \& BAIRD G.C. (eds.), 
Paleontologic Events, Columbia University Press, New York.

Best M.M.R. \& KidweLl S.M. 1995 - Bivalve shell taphonomy in tropical siliciclastic marine environments: preliminary experimental results. Sixth North American Paleontological Convention Abstracts of Papers, Paleontological Society Special Publications, 8: 34.

BRANDT D.S. 1985 - Ichnologic, taphonomic, and sedimentologic clues to the deposition of Cincinnatian shales (Upper Ordovician), Ohio, U.S.A.: 299-307. In CuRRAN A.H. (ed.), Biogenic Structures: Their Use in Interpreting Depositional Environments. Society of Economic Paleontologists and Mineralogists Special Publication, 35.

BRANDT D.S. 1986 - Preservation of event beds through time. Palaios, 1: 92-96.

BRANDT D.S. 1989 - Taphonomic grades as a classification for fossiliferous assemblages and implications for paleoecology. Palaios, 4: 303-309.

BRETT C.E. 1995 - Sequence stratigraphy, biostratigraphy, and taphonomy in shallow marine environments. Palaios, 10: 597-616.

BRETT C.E. \& BAIRD G.C. 1993 - Taphonomic approaches to temporal resolution in stratigraphy: examples from Paleozoic marine mudrocks: 250-274. In Kidwell S.M. \& BerHirensmeYer A.K. (eds.), Taphonomic Approaches to Time Resolution in Fossil Assemblages. Short Courses in Paleontology, 6, Paleontological Society, Tulsa.

Brett C.E. \& SeILACher A. 1991 - Fossil Lagerstätten: A taphonomic consequence of event sedimentation: 283-297. In Einsele G., Bayer U. \& Seilacher A. (eds.), Cycles and Events in Stratigraphy, SpringerVerlag, Berlin.

BUTTERFIELD N.J. 1995 - Secular distribution of BurgessShale-type preservation. Lethaia, 28, 113 p.

Cummins H., Powell E.N., Stanton R.J.JR. \& Staff G. 1986 - The rate of taphonomic loss in modern benthic habitats: how much of the potentially preservable community is preserved? Palaeogeography, Palaeoclimatology, Palaeoecology, 52: 291-320.

Davies D.J., Powell E.N. \& Stanton R.J.JR. 1989 Taphonomic signature as a function of environmental process: shells and shell beds in a hurricaneinfluenced inlet on the Texas coast. Palaeogeography, Palaeoclimatology, Palaeoecology, 72: 317-352.

DrISCOLL E.G. 1970 - Selective bivalve destruction in marine environment, a field study. Journal of Sedimentary Petrology, 40: 898-905.

FELS A. \& SEYFRIED H. 1993 - "A la recherche du temps perdu": On geological condensation, with examples from the Jurassic Subbetic Plateau in southeastern Spain. Neues Jahrbuch für Geologie und Paläontologie Abhandlungen, 189: 13-31.

FLESSA K.W. 1993 - Time-averaging and temporal resolution in Recent shelly faunas: 9-33. In KIDWELL S.M. \& BERHRENSMEYER A.K. (eds.), Taphonomic Approaches to Time Resolution in Fossil Assemblages. Short Courses in Paleontology, 6, Paleontological Society, Tulsa.

Flessa K.W., Cutler A.H. \& Meldafl K.H. 1993 - Time and taphonomy: quantitative estimates of time-ave- raging and stratigraphic disorder in a shallow marine habitat. Paleobiology, 19: 266-286.

FLESSA K.W. \& KoWALEWSKI M. 1994 - Shell survival and time-averaging in nearshore and shelf environments: estimates from the radiocarbon literature. Lethaia, 27: 153-165.

FREY R.W. \& HowARD J.D. 1986 - Taphonomic characteristics of offshore mollusk shells, Sapelo Island, Georgia. Tulane Studies in Geology and Paleontology, 19: 51-61.

FÚRSICH F.T. 1975 - Trace fossils as environmental indicators in the Corallian of England and Normandy. Lethaia, 8: 151-172.

Funsich F.T. 1978 - The influence of faunal condensation and mixing of the preservation of fossil benthic communities. Lethaia, 11:243-250.

FÚRSich F.T. \& ABERHAN M. 1990 - Significance of timeaveraging to palaeocommunity analysis. Lethaia, 23 : 143-152.

FURSICH F.T. \& FLESSA K.W. 1991 - The origin and interpretation of Bahia la Choya (northern Gulf of California) taphocoenoses: implications for paleoenvironmental analysis. Zitteliana, 18: 165-169.

FÚRSICH F.T. \& KaUfFman E.G. 1984 - Palaeoecology of marginal marine sedimentary cycles in the Albian Bear River Formation of south-western Wyoming. Palaeontology, 27: 501-536.

Furrstch F.T. \& OschmanN W. 1993 - Shell beds as tools in basin analysis: the Jurassic Kachchh, western India. Journal of the Geological Society London, 150: 169185.

FÜrsich F.T., OschmanN W., SinGH I.B. \& JatTLY A.K. 1992 - Hardgrounds, reworked concretion levels and condensed horizons in the Jurassic of western India: their significance for basin analysis. Journal of the Geological Society of London, 149: 313-331.

GOMEZ J.J. \& FERNANDEZ-López S. 1994 - Condensation processes in shallow platforms. Sedimentary Geology, 92: 147-159.

HALLAM A. 1972 - Models involving population dynamics: 62-80. In Schopf T.J.M. (ed.), Models in Paleobiology, Freeman Cooper and Co., San Francisco.

HEIM A. 1934 - Stratigraphische Kondensation. Eclogae Geologica Helvetica, 27: 372-383.

HeNDerson S.W. \& Frey R.W. 1986 - Taphonomic redistribution of mollusk shells in a tidal inlet channel, Sapelo Island, Georgia. Palaios, 1: 3-16.

HoLLAND S.M. 1993 - Sequence stratigraphy of a carbonate-clastic ramp: the Cincinnatian Series (Upper Ordovician) in its type area. Geological Society of America Bulletin, 105: 306-322.

HoLLAND S.M. 1995 - The stratigraphic distribution of fossils. Paleobiology, 21: 92-109.

JENKYNS H. 1971 - The genesis of condensed sequences in the Tethyan Jurassic. Lethaia, 4: 327-352.

Jomnson R.G. 1960 -Models and methods for analysis of the mode of formation of fossil assemblages. Geological Society of America Bulletin, 71: 1075-1085.

KIDWELL S.M. 1982 - Time scales of fossil accumulation: patterns from Miocene benthic assemblages. Third North American Paleontological Convention Proceedings, 1: 295-300. 
KIDWELL S.M. 1989 - Stratigraphic condensation of marine transgressive records: origin of major shell deposits in the Miocene of Maryland. Journal of Geology, 97, 24 p.

KIDWELL S.M. 1991a - The stratigraphy of shell concentrations: 211-290. In ALLISON P.A. \& BRIGGS D.E.G. (eds.), Taphonomy: Releasing the Data Locked in the Fossil Record, Plenum Press, New York.

KidWELL S.M. 1991b - Condensed deposits in siliciclastic sequences: expected and observed features: 682-695. In Einsele G., Ricken W. \& SeLlacher A. (eds), Cycles and Events in Stratigraphy, Springer Verlag, Berlin.

KIDWELL S.M. 1993a - Patterns of time-averaging in the shallow marine fossil record: 275-300. In KIDwELL S.M. \& BerhrensmeYer A.K. (eds.), Taphonomic Approaches to Time Resolution in Fossil Assemblages. Short Courses in Paleontology, 6, Paleontological Society, Tulsa.

KIDWELL S.M. 1993b - Taphonomic expressions of sedimentary hiatus: field observations on bioclastic concentrations and sequence anatomy in low, moderate and high subsidence settings. Geologische Rundschau, 82: 189-202.

KIDWELL S.M. \& AIGNER T. 1985 - Sedimentary dynamics of complex shell beds: implications for ecological and evolutionary patterns: 382-395. In BAYER U. \& SeILACHer A. (eds.), Sedimentary and Evolutionary Cycles, Springer Verlag, Berlin.

KIDWELL S.M. \& BoSENCE D.W.J. 1991 - Taphonomy and time-averaging of marine shelly faunas: 115-209. In Allison P.A. \& BRigGs D.E.G. (eds.), Taphonomy: Releasing the Data Locked in the Fossil Record, Plenum Press, New York.

KIDWELL S.M. \& BRENCHLEY P.J. 1996 - Evolution of the fossil record: thickness trends in marine skeletal accumulations and their implications: 290-336. In JABLONSKI D., ERWIN D.H. \& LIPPS J.H. (eds.); Evolutionary Paleobiology, University Chicago Press, Chicago.

KIDWELL S.M. \& FLESSA K.W. 1995 - The quality of the fossil record: populations, species, and communities. Annual Review of Ecology and Systematics, 26: 269299.

KOWALEWSKI M. 1996 - Time-averaging, overcompleteness, and the geological record. Journal of Geology, 104: 317-326.

KoWALEWSKI M. \& FLESSA K.W. 1996 - Improving with age: the fossil record of lingulide brachiopods and the nature of taphonomic megabiases. Geology, 24: 977-980.

Kowalewski M., Flessa K.W. \& Hallman D.P. 1995 Ternary taphograms: triangular diagrams applied to taphonomic analysis. Palaios, 10: 478-483.

KraWtNKel H. \& SeYFried H. 1996 - Sedimentologic, palaeoecologic, taphonomic and ichnologic criteria for high resolution sequence analysis: a practical guide for the identification and interpretation of discontinuities in shelf deposits. Sedimentary Geology, 102: 79-110.

LI X. \& Droser M.L. 1997 - Nature and distribution of Cambrian shell concentrations: evidence from the Basin and Range Province of the western United States (California, Nevada, and Utah). Palaios, 12: 111-126.
MACHALSKI M. \& WALASZCZYK I. 1987 - Faunal condensation and mixing in the uppermost Maastrichtian/ Danian Greensand Middle Vistula Valley, Central Poland). Acta Geologica Polonica, 37: 74-91.

MARSHALL C.R. 1997 - Confidence intervals on stratigraphic ranges with nonrandom distributions of fossil horizons. Paleobiology, 23: 165-173.

MARTIN R.E., HaRRIS M.S. \& LidDELL W.D. 1995 Taphonomy and time-averaging of foraminiferal assemblages in Holocene tidal flat sediments, Bahia la Choya, Sonora, Mexico (northern Gulf of California). Marine Micropaleontology, 26: 187-206.

Martin R.E., Wehmiller J.F., HaRris M.S. \& Liddell W.D. 1996 - Comparative taphonomy of bivalves and foraminifera from Holocene tidal flat sediments, Bahia la Choya, Sonora, Mexico (northern Gulf of California): taphonomic grades and temporal resolution. Paleobiology, 22: 80-90.

Meldaft K.E., Flessa K.W. \& Cutler A.H. 1997 - Timeaveraging and postmortem skeletal survival in benthic fossil assemblages: quantitative comparisons among Holocene environments. Paleobiology, 23: 207-229.

NeLSON C.S., KeANE S.L. \& HEAd P.S. 1988 - Non-tropical carbonate deposits on the modern New Zealand shelf. Sedimentary Geology, 60: 71-94.

PARsons K.M, Brett C.E. \& Miller K.B. 1988 Taphonomy and depositional dynamics of Devonian shell-rich mudstones. Palaeogeography, Palaeoclimatology, Palaeoecology, 63: 109-139.

Peterson C.H. 1976 - Relative abundances of living and dead molluscs in two California lagoons. Lethaia, 9: 958-965.

Plotnick R.E, McCarroll S. \& Powell E.N. 1990 - Crab death assemblages from Laguna Madre and vicinity, Texas. Palaios, 5: 81-87.

Powell E.N., STafF G., Davies D.J. \& Caldendar W.R. 1989 - Macrobenthic death assemblages in modern marine environments: formation, interpretation, and application. CRC Critical Reviews in Aquatic Science, 1: 555-589.

PowELL E.N. \& DAviEs D.J. 1990 - When is an "old" shell really old? Journal of Geology, 98: 823-844.

Roy K., VAlentine J.W., Jablonski D. \& Kidwell S.M. 1996 - Scales of climatic variability and time-averaging in Pleistocene biotas: implications for ecology and evolution. Trends in Ecology and Evolution, 11: 458-463.

SEILACHER A. 1985 - The Jeram model: event condensation in a modern intertidal environment: $336-346$. In Bayer U. \& Seilacher A. (eds.), Sedimentary and Evolutionary Cycles, Springer-Verlag, Berlin.

SePKoski J.J.JR., BAmBACH R.K. \& DRoser M.L. 1991 Secular changes in Phanerozoic event bedding and the biological overprint: 298-312. In EINSELE G., Ricken W.\& SeIlacher A. (eds.), Cycles and Events in Stratigraphy, Springer Verlag, Berlin.

VAN DER VALK L. 1991 - Molluscan shell distribution and sediments of the fossil and modern upper shoreface of the coast of Holland (Holocene, W. Netherlands). Contributions to Tertiary and Quaternary Geology, 28: 13-28. 
WALKER K.R. \& BAMBACH R.K. 1971 - The significance of fossil assemblages from fine-grained sediments: time-averaged communities. Geological Society of America Abstracts with Programs, 3: 783-784.

WeHMIller J.F., BelknAP D.F., Boutin B.S., Mirecki J.E., RAHAIM S.D. \& YoRK L.L. 1988 - A review of the aminostratigraphy of Quaternary mollusks from United States Atlantic Coastal Plain sites. Geological Society of America Special Papers, 227: 69-110.

WEHMILLER J.F. \& YORK L.L. 1992 - Aminostratigraphic evaluation of the sources of shells in modern beach deposits: Edisto Beach, South Carolina. Geological Society of America Abstracts with Programs, 24: 72.

WEHMILLER J.F., YoRK L.L. \& BART M.L. 1995 - Amino acid racemization geochronology of reworked Quaternary mollusks on US Atlantic coast beaches: implications for chronostratigraphy, taphonomy, and coastal sediment transport. Marine Geology, 124: 303-337.

WendT J. \& Aigner T. 1985 - Facies patterns and depositional environments of Paleozoic cephalopod limestones. Sedimentary Geology, 44: 263-300.

WILSON J.E. 1988 - A model for temporal changes in the faunal composition of shell gravels during a transgresssion on the continental shelf around the British Isles. Sedimentary Geology, 60: 95-105.

\section{S.M. KIDWELL}

Department of Geophysical Sciences University of Chicago 5734 South Ellis Avenue Chicago, II. 60637, U.S.A. skidwell@midway.uchicago.edu 